provided. All those concerned must feel a deep sense of satisfaction in the successful accomplishment of this day's difficult programmes. For the first time in history, the general public in all parts of the world were enabled to participate in very intimate detail in the elaborate ceremony of the coronation of a British king. Hitherto this experience has been confined to the few who, by virtue of rank or service, have been favoured with a position inside Westminster Abbey.

Coronatron DAy, 1937, will be remembered by many millions of people who heard, either in their own homes or while they were actually in position along the processional route, a continuous broadcast commentary accompanied by a sound picture background of the pomp and majesty of the procession and ceremony. A striking illustration of the advantages which broadcasting gives over the possible scope of the ordinary sightseer, was provided by the manner in which the commentary was successively switched forward along the route, so that the listener was enabled to keep up with the progress of the procession. When, as seems undoubtedly probable in the near future, this advantage becomes available to the viewer as well as to the listener, it will be still more generally appreciated. When the picture is further provided in natural colours, the entire scope of the participation of the general public in large-scale ceremonies will have been subject to a revolutionary change.

THE evening programme comprised messages of homage to the new King, presented by speakers in various parts of the Empire in addition to the official greetings from the Prime Ministers or other representatives of the Dominions actually present in London. This expression of homage from the Empire concluded with a speech by H.M. King George VI, who himself recorded the fact that this was the first time that the King had been able to address the nation as a whole on the day of his coronation. Messages congratulating the B.B.C. on these impressive broadcasts have been received from all parts of the Empire and from many foreign lands. These marked the successful use of the two new $50 \mathrm{~kW}$. transmitters at the Daventry short-wave station supplementing the older $10 \mathrm{~kW}$. sets. In many cases, the resulting reception was so satisfactory as to permit the rebroadcasting of the programme through all local transmitters. For example, in Melbourne the broadcast was retransmitted from ninety-seven stations throughout Australia. The Corporation's aim to supply the whole world with an effective broadcasting service was thus realized on this occasion. Truly may it be said that radio broadcasting is a very potent factor in bringing together the peoples of the world to a closer union which should result in greater friendliness and understanding.

\section{Natural Limits of Human Flight}

In his presidential address delivered before the Royal Aeronautical Society on April 26, Mr. H. E. Wimperis discussed the "Natural Limits of Human
Flight". He showed how relatively thin is the atmospheric shell in which we live. Birds, he considers, have reached the limits of perfection in natural flight, comparatively little progress having been made in the last thirty million years, whilst the "present attainments in human flight have all grown from the endeavours of a single generation". With regard to high speed, increase in altitude of flight does not necessarily mean an increase in speed, but depends largely upon the supercharging of the engine. Increase of altitude has also other detrimental effects, for example, increase of drag coefficient due to decrease of Reynolds' number, and increase in induced drag due to the increase in incidence when flying near the 'ceiling'. Actual increase in the size of aircraft would raise the speed; but not beyond a certain point, unless more engine power can be got from a given space, or some means found of reducing the drag by changing the turbulent flow to a laminar one. Progress along these lines will soon bring us to the most formidable obstacle of all, namely, the compressibility of the air as the speed of sound is approached; and this Mr. Wimperis regards as being well above the limit obtainable with engines of the type in use to-day, which he placed as between 500 and 600 m.p.h.

Power of manœuvre was the next point considered by Mr. Wimperis. Speed of dive, which also involves large changes in altitude, has apparently no harmful effects on the personnel of an aircraft. On the other hand, rapid changes in direction or speed bring into play accelerations which impose severe physiological effects on the personnel, and limit the maximum acceleration to the order of ten times gravity. Consequently, with steadily increasing speeds the rate of manœuvre must thus be correspondingly de. creased. With regard to the limit of altitude, provided oxygen apparatus is used, flights at 80,000 feet are possible, but increase in altitude above the present limit of 50,000 feet will be restricted to 60,000 feet largely by supercharging difficulties alone. Speaking of the range of flight, Mr. Wimperis said that it is difficult to set a limit to it. In still air, range is independent of altitude and depends chiefly on engine fuel consumption economy, low drag, low structure weight, coupled with large fuel capacity. He also expressed the opinion that aircraft as weapons of attack in warfare will, in the future, not occupy such a favourable position as in the past.

\section{Long Ashton Research Station}

The annual open day of the University of Bristol Research Station at Long Ashton was held on May 6, when horticulturists, cider makers and fruit growers assembled to sample the ciders and other fruit products of the current season. Prizes awarded for the production of cider fruit were presented by Lord Faversham, Parliamentary Secretary to the Minister for Agriculture, after a speech which was broadcast from the West Regional Station. The results of recent investigations in cider making were on view. These included the use of German wine yeasts such as Waldenberg, Steinberg and Zeltingen instead of 
natural cider yeasts, to obtain finer flavour. Artificially and naturally sweetened ciders have been compared, and apple juice has been successfully concentrated for storage purposes. The production of non-alcoholic apple juices has received considerable attention in the past year. Various combinations of dessert, culinary and cider varieties have been used for this purpose, and the effects of aeration and pasteurization studied. Seitz-filtered still juices are considered the most attractive, pasteurization having an adverse effect on flavour. As a result of the work at Long Ashton, commercial production of syrups from pure soft-fruit juices is now in operation on a large scale, and the numerous domestic uses of these products were illustrated by an exhibit of milk shakes, jellies, cake fillings, etc.

Experiments in progress on the extensive fruit plantations of the Station were open for inspection. These include investigations on the manuring of apples and soft fruits, pruning and shaping of fruit trees, rootstock trials with apples, pears and plums, and the influence of cultural treatment on the storage qualities of apples. Of particular interest on this occasion was the attempt to grow cider varieties of vintage quality as bush trees. If this can be accomplished, crops may be borne in a much shorter time than by the usual method of standard tree production. The propagation of basket and cricket bat willows also aroused considerable interest. Progress in methods of pest and disease control was illustrated by exhibits in the laboratories, a recent development being the use of cuprous oxide as a seed treatment for early peas and zinc oxide for ornamentals. The control of plum sawfly and red spider was demonstrated by the use of combined washes containing white oil emulsion and rotenonecontaining substances. In addition to horticultural research, the extensive agricultural advisory service of the Station was evident from the exhibits on dairy bacteriology, methods of pig husbandry and the economic feeding of dairy herds.

\section{The Patent Office Library}

ON May 3 Dr. Leslie Burgin, M.P. (Parliamentary Secretary of the Board of Trade), accompanied by the Comptroller-General of Patents and other officials, received a deputation from the Parliamentary Science Committee which placed before him its report on various desired improvements in accommodation and other amenities at the Patent Office. The deputation was introduced by Lieut.-Colonel Sir Arnold Wilson, M.P. Dr. Burgin expressed himself most sympathetically towards the points raised, several of which, he stated, were already being dealt with, or were in contemplation. He was precluded at present from discussing the provision of a set of duplicate search files by the adverse findings on that subject of the Sargant Committee of 1931. If, however, the Parliamentary Science Committee presented a detailed case strong enough to justify him in re-opening that subject, he would not bar and bolt the door; but the onus of justification must rest with the Committee. Dr. Burgin stated that an extension of the
Patent Office buildings was contemplated during the next few years which would allow for increased library space. On the subject of binding, he said that allocations amounting to $£ 3,100$ had been made since the Great War for the purpose of overtaking arrears, apart from substantial increases in the grant for books and binding, which had permitted of enlarged purchases of foreign publications. If the Committee would provide him with specific particulars of the foreign publications and periodicals which, in its opinion, should be added to the Library, every endeavour would be made to meet such suggestions. The deputation was satisfied that improvements in the services afforded by the Patent Office Library are in hand, and that the importance of the matters laid by them before the Board of Trade was fully appreciated by Dr. Burgin and by the officials concerned.

\section{Preservation of Monuments of Antiquity}

IN a period of economic transition such as the present, the future of many monuments of antiquity, now in private ownership, even when under the protection of the Office of Works, must continue to be precarious, owing to the breaking up of large estates. Private benefaction and public response to appeal in cases of urgent necessity have been generous in recent years ; but they cannot be expected to shoulder the burden indefinitely. The strongest safeguard for the less widely known, but often none the less important antiquities, which necessarily must run the greater risk, is a vigilant educated public opinion, backed by an enlightened authority. An example of the effective application of existing legislation in such conditions is afforded by the recent public inquiry at Worthing on a proposal to develop Highdown Hill between Worthing and Littledown as a building estate (The. Times, May 13). On account of the natural, archæological and historical interest of the site, this inquiry, held by order of the Ministry of Health, is to be regarded as of considerable importance. The Hill, a southern outlier of the South Downs, rises to a height of two hundred and sixtynine feet, and is an important feature in the maritime level tract, which is visible from far along the coast. On the summit is an earthwork, of at present uncertain age, in which was discovered in 1892 an important sixth century Anglo-Saxon cemetery. In it were eighty-six burials lying east and west in rows. The contents of the graves, of which the ornamentation suggested Frankish affinities, made this one of the most important finds of its kind in Britain. Yet the site was not scheduled under the Ancient Monuments Acts until 1930, and then only as the result of public protest, when the estate was offered for sale. The present inquiry was held on an appeal from the owner against a refusal of the Worthing Rural District Council to grant an interim development order. It was opposed by the Worthing Rural and Town Councils, the West Sussex County Council and four adjacent owners. A public-spirited offer has been made by the local authorities to accept any financial responsibility involved in the preservation of the site. 